\title{
Genetic Structure of the Invasive Tree Ailanthus altissima in Eastern United States Cities
}

\author{
Preston R. Aldrich, ${ }^{1}$ Joseph S. Briguglio, ${ }^{1}$ Shyam N. Kapadia, ${ }^{1}$ Minesh U. Morker, ${ }^{1}$ \\ Ankit Rawal, ${ }^{1}$ Preeti Kalra, ${ }^{1}$ Cynthia D. Huebner, ${ }^{2}$ and Gary K. Greer ${ }^{3}$
}

${ }^{1}$ Department of Biological Sciences, Benedictine University, Lisle, IL 60532, USA

${ }^{2}$ Northern Research Station, USDA Forest Service, 180 Canfield Street, Morgantown, WV 26505, USA

${ }^{3}$ Biology Department, Grand Valley State University, 228 Henry Hall, 1 Campus Drive, Allendale, MI 49401, USA

Correspondence should be addressed to Preston R. Aldrich, paldrich@ben.edu

Received 18 June 2010; Accepted 21 August 2010

Academic Editor: Stephen W. Adkins

Copyright ( $) 2010$ Preston R. Aldrich et al. This is an open access article distributed under the Creative Commons Attribution License, which permits unrestricted use, distribution, and reproduction in any medium, provided the original work is properly cited.

\begin{abstract}
Ailanthus altissima is an invasive tree from Asia. It now occurs in most US states, and although primarily an urban weed, it has become a problem in forested areas especially in the eastern states. Little is known about its genetic structure. We explore its naturalized gene pool from 28 populations, mostly of the eastern US where infestations are especially severe. Five microsatellite markers were used to examine presumed neutral genetic variation. Results show a gene pool that is moderately diverse and sexually active and has significant but small genetic differences among populations and little correspondence between geographic and genetic distance. These findings are consistent with a model of multiple introductions followed by high rates of gene exchange between cities and regions. We propose movement along road and railway systems as the chief mode of range expansion.
\end{abstract}

\section{Introduction}

Ailanthus altissima Swingle (stinking ash, Tree-of-Heaven, Chinese sumac) is a widespread member of the tropical tree family Simaroubaceae (Quassia family). Clayton et al. [1] recently clarified phylogenetic relationships within the family. The genus Ailanthus has five recognized extant species. Though four of these are geographically restricted to the Paleotropics, A. altissima is widespread in the New World [2]. Individuals of some of the other species may be present in the United States botanical gardens, but it is thought that naturalized Ailanthus is comprised mostly of the single species A. altissima (hereafter, Ailanthus), though genetic evidence is lacking at present.

The first documented introduction of Ailanthus into the U.S. was through England in 1784 by William Hamilton, a Philadelphia gardener. Subsequent introductions have occurred along the east coast, and numerous introductions are thought to have occurred in the west most notably by Chinese immigrant railroad workers who used the plant as a medicinal in the 1800 s [3]. The species has since spread to most states in the U.S. [4] following human disturbances $[3,5]$.

Ailanthus is shade intolerant and an aggressive pioneer, able to grow in the cracks in concrete [6]. It has large pinnate leaves similar to ash (Fraxinus) though the overall growth form is tropical with indeterminate leaf growth producing gently swooping leaves over a meter long. The species is dioecious [7] and pollinated mainly by bees and flies [8]. Juvenile growth is rapid accompanied with early reproduction [9]. Though clonal growth is aggressive, seed production is prolific with a single adult female producing 300,000 seed in a season $[9,10]$. Seeds are samaras and are known to be wind dispersed $[11,12]$.

Ailanthus is relatively well-studied for its toxins which inhibit the growth of other plants and render Ailanthus unpalatable to many U.S. herbivores [13-16]. Kowarik and Säumel [17] provide a recent review of Ailanthus altissima biology. Despite numerous bioassay studies, little is known regarding naturalized geographic variation in the species, 
be it biochemical or genetic. A small isozyme survey [18] showed no reduction in variation of U.S. relative to Chinese Ailanthus.

We investigate the microsatellite genetic structure of eastern U.S. Ailanthus populations addressing the following three questions: (1) is the gene pool diverse, and if so, are there pockets of high variation and/or endemism? (2) How does the species partition its variation within and among populations (cities), and does this vary with population size? We anticipate that larger cities experience a greater flux of people and that Ailanthus seed dispersal is strongly tied to human population movement. (3) Are there genetic signatures of prior introductions? We predict that eastern individuals will be most similar to the first immigrants into Philadelphia but that long distance dispersal has resulted in allele sharing with the western section of the gene pool.

\section{Materials and Methods}

2.1. Field Collections. We collected Ailanthus in urban centers across the eastern U.S. during the summers of 2005-2007. Sampling intensity was greatest in and around West Virginia which is one of several eastern states with a high Ailanthus density. We present data for 555 trees from 28 sampling locations (Table 1, Figure 1), each location representing a population of 20 adult Ailanthus on average. In a few cases, a sampling location included more than one adjacent city. The two most western sample locations were atypical and included collections from neighboring states (IllinoisIndiana (IL/IN), California-Utah-Colorado (CUC)).

Sample sites included regions thought to be primary points of introduction of the species into the U.S. The Woodlands, the 18th century plantation of William Hamilton in Philadelphia, PA, is thought to be the original point of introduction of Ailanthus into the U.S. [3]. We sampled several trees there including three very large Ailanthus that might have been planted by Hamilton, though this species likely only lives about 50 years. More likely, the sample trees represent generational sprouts from these trees, or at the very least, early-generation members of the U.S. gene pool. Introductions of Ailanthus into the western U.S. coast during the 1800 s by Chinese immigrant workers were likely more numerous and diffuse, and our sampling there includes three states.

Samples were collected as leaf tissue, or in a few cases seed. Trees sampled were separated by at least $50 \mathrm{~m}$ to prevent repeated sampling of the same gene, given the propensity for Ailanthus to propagate clonally. In order to represent the diversity present in large cities, no more than five trees were sampled in a single "neighborhood" of a city, at which point a car was used to travel to another locale to continue sampling. Leaf tissue was placed on ice in the field and then frozen within the week upon return to the laboratory. Collections from the far western states (CA, CO, and UT) were sampled by seed, whereby seed stock was grown at Benedictine University greenhouse and a single seedling per family harvested for DNA.
2.2. Genetics. Total genomic DNA was extracted from leaf tissue using the DNeasy Plant Minikit (Qiagen). Tissue was pulverized using the Bead Beater (BioSpec, Bartlesville, OK), using modifications of a protocol for oaks [19]. We carried out genotyping using five microsatellite primer pairs (Aa22, Aa69, Aa75, Aa76, and Aa82) developed for Ailanthus altissima by Dallas et al. [20]. Template concentrations were adjusted to roughly $5-10 \mathrm{ng} / \mu \mathrm{L}$. Polymerase chain reaction (PCR) amplifications ( $20 \mu \mathrm{L}$ volume) included $1 \times E x$ Taq buffer (Invitrogen, Carlsbad, Calif. USA; proprietary except for $2.0 \mathrm{mmol} / \mathrm{L} \mathrm{MgCl}_{2}$ ), $100 \mu \mathrm{mol} / \mathrm{L}$ dNTP each, $72 \mathrm{nmol} / \mathrm{L}$ of each upper and lower primer, $0.01 \mathrm{U}$ of Takara $E x$ Taq polymerase $/ \mu \mathrm{L}$ (Invitrogen), and $0.2-0.4 \mathrm{ng} \mathrm{DNA} / \mu \mathrm{L}$ BSA was (bovine serum albumin). The adjuvant BSA proved critical to amplification of several of the samples. Based simply on odor, individuals differed greatly in their volatile chemistry, and some of these compounds may have interfered with polymerase function. The saturation of the reaction with inert BSA protein may have slowed the polymerase degradation. PCR profiles were $94^{\circ} \mathrm{C}$ for $1 \mathrm{~min}$; 40-50 cycles of $94^{\circ} \mathrm{C}$ for $30 \mathrm{~s}, \mathrm{Ta}$ for $45 \mathrm{~s}$, and $72^{\circ} \mathrm{C}$ for $1.5 \mathrm{~min}$; and $72^{\circ} \mathrm{C}$ for $10 \mathrm{~min}$. Forward primers were $5^{\prime}$-end labeled with dyes. We analyzed fragment sizes on LiCor 4200 and 4300 machines (Beckman Coulter, Inc., Fullerton, Calif.) using $6.5 \%$ polyacrylamide and a 700 -bp LiCor standard.

2.3. Data Analysis. Standard descriptive statistics were used to evaluate genetic diversity and endemism along with the partitioning of variation. We also used a Bayesian assignment procedure to infer the number of genetic subdivisions within our sampling scheme. All of these points of evidence were brought to bear on the issue of introduction history.

2.3.1. Diversity and Endemism. Standard genetic diversity estimates were obtained using GDA v1.0 (Genetic Data Analysis, [21]) and GENEPOP v4.0 [22]. The distributions of allelic richness and private alleles were also evaluated using the program ADZE [23] which avoids bias in sample sizes through rarefaction, randomly subsampling sets of size $g$ from each population. Global tests of heterozygote deficiency and excess were made using GENEPOP under default parameters. We compared several diversity measures for Ailanthus populations grouped by the size of the human population of a city (Table 1 ). Cities with $<10,000$ people were categorized as "small", using the 2,000 Census (U.S. Census Bureau, http://www.census.gov/). Nonparametric comparisons of groups were performed in Matlab using the two-sided Mann-Whitney $U$-test.

\subsubsection{Partitioning of Genetic Variation. We explored genetic structure in two ways. Firstly, we assumed that the city-based population structure reflected in our sampling was biologi- cally valid and meaningful, and we calculated traditional $F$ - statistics and migration rates from these estimates. Secondly, we released the assumption that sampled populations rep- resent biological populations and sought to infer the actual number of populations within the Ailanthus gene pool, to the extent that we had sampled it.}


TABle 1: Twenty-eight Ailanthus city populations sampled and the associated summary gene diversity statistics based on five nuclear microsatellite markers.

\begin{tabular}{|c|c|c|c|c|c|c|c|c|}
\hline Tate & City & $N_{H}$ & $N_{A}$ & $n$ & $A$ & $H_{e}$ & $H_{o}$ & $f$ \\
\hline $\mathrm{AL}$ & Huntsville & 158.2 & 11 & 11 & 4 & 0.632 & 0.582 & 0.083 \\
\hline${ }^{\dagger} \mathrm{CA} / \mathrm{UT} / \mathrm{CO}$ & Sacramento $^{\mathrm{a}}$ & 181.5 & 17 & 16.6 & 4 & 0.685 & 0.627 & $0.087^{* *}$ \\
\hline IL/IN & Chicago $^{\mathrm{b}}$ & $2,035.80$ & 24 & 20.8 & 4.6 & 0.692 & 0.728 & -0.055 \\
\hline $\mathrm{KY}$ & Louisville & 256.2 & 17 & 16.6 & 4.2 & 0.682 & 0.683 & -0.001 \\
\hline MD & Baltimore $^{\mathrm{c}}$ & 377.6 & 24 & 22.8 & 4 & 0.663 & 0.587 & $0.116^{* *}$ \\
\hline \multirow[t]{2}{*}{$\mathrm{OH}$} & Cleveland & 478.4 & 20 & 19.8 & 3.6 & 0.662 & 0.626 & 0.056 \\
\hline & Dayton & 166.2 & 20 & 20 & 4.8 & 0.664 & 0.58 & $0.129 * *$ \\
\hline \multirow[t]{2}{*}{${ }^{\dagger} \mathrm{PA}$} & Philadelphia & $1,517.60$ & 20 & 18.2 & 3.6 & 0.637 & 0.656 & -0.031 \\
\hline & Pittsburgh & 334.6 & 23 & 22.8 & 3.8 & 0.605 & 0.596 & 0.016 \\
\hline $\mathrm{TN}$ & Nashville & 545.5 & 26 & 25 & 4 & 0.639 & 0.671 & -0.050 \\
\hline TX & Austin & 656.6 & 15 & 14.6 & 3.6 & 0.615 & 0.741 & $-0.212^{*}$ \\
\hline \multirow[t]{4}{*}{ VA } & Harrisonburg & 40.5 & 21 & 21 & 4 & 0.664 & 0.524 & $0.215^{* *}$ \\
\hline & Lexington & 6.9 & 15 & 15 & 3.8 & 0.576 & 0.573 & 0.005 \\
\hline & Roanoke & 94.9 & 26 & 24.8 & 4.4 & 0.659 & 0.653 & 0.01 \\
\hline & Wytheville & 7.8 & 18 & 17.2 & 3.6 & 0.532 & 0.515 & 0.031 \\
\hline \multirow[t]{13}{*}{ WV } & Buckhannon & 5.7 & 23 & 22.8 & 4.2 & 0.632 & 0.651 & -0.029 \\
\hline & Charleston & 53.4 & 22 & 21 & 3.6 & 0.598 & 0.526 & $0.121^{* *}$ \\
\hline & Clarksburg & 16.7 & 22 & 21.6 & 4.4 & 0.661 & 0.639 & 0.034 \\
\hline & Harpers Ferry ${ }^{\mathrm{d}}$ & 1.2 & 21 & 20.4 & 3.8 & 0.675 & 0.578 & $0.147^{* *}$ \\
\hline & Hartland & 0.1 & 17 & 15.8 & 3.8 & 0.617 & 0.585 & 0.054 \\
\hline & Huntington & 51.4 & 20 & 19.8 & 4.4 & 0.685 & 0.589 & $0.144^{* *}$ \\
\hline & Lewisburg & 3.6 & 14 & 12.2 & 3.4 & 0.537 & 0.328 & $0.399^{* *}$ \\
\hline & Mahan & 0.1 & 20 & 18.6 & 2.8 & 0.459 & 0.354 & $0.232 * *$ \\
\hline & Martinsburg & 15 & 20 & 19.4 & 3.8 & 0.633 & 0.619 & 0.022 \\
\hline & Morgantown & 26.8 & 25 & 25 & 3.8 & 0.592 & 0.504 & $0.152^{* *}$ \\
\hline & Parkersburg & 33.1 & 20 & 19.2 & 4 & 0.693 & 0.6 & $0.137^{* *}$ \\
\hline & Sharon & 0.1 & 19 & 18.4 & 4.2 & 0.609 & 0.591 & 0.03 \\
\hline & Welch $^{\mathrm{e}}$ & 4 & 19 & 19 & 4.2 & 0.617 & 0.642 & -0.043 \\
\hline MEAN & & 252.5 & 20 & 19.3 & 3.9 & 0.629 & 0.591 & 0.062 \\
\hline
\end{tabular}

AL, Alabama; CA, California; CO, Colorado; IL, Illinois; IN, Indiana; KY, Kentucky; MD, Maryland; OH, Ohio; PA, Pennsylvania; TN, Tennessee; TX, Texas; UT, Utah; VA, Virginia; WV, West Virginia.

$N_{H}$, human individuals in city $\times 1,000$ (2000 Census); $N_{A}$, Ailanthus individuals sampled from this city; $n$, sample size for estimate of genetic parameters; $A$, number of alleles per locus; $H_{e}$, expected heterozygosity; $H_{o}$, observed heterozygosity; $f$, inbreeding coefficient.

${ }^{*} P<.05,{ }^{* *} P<.01$ one-sided test of departure from Hardy-Weinberg expectations.

${ }^{\dagger}$, likely points of introduction into the United States between 1750 and 1850.

a, Sacramento, CA (5); Pleasant Grove, UT (1); Provo, UT (2); Springville, UT (2); Denver, CO (5); Fort Collins, CO (1); Greeley, CO (1).

b, Illinois, western Chicago suburbs (15); Indiana: West Lafayette, IN (9).

', Baltimore, MD (13); Frederick, MD (8); Annapolis, MD (3).

d, Harpers Ferry, WV (13); Charles Town, WV (8).

e, Welch, WV (15); Bluefield, WV (3); Keystone, WV (1).

For traditional genetic structure, $F$-statistics $[24,25]$, $F\left(F_{\text {it }}\right), \theta\left(F_{\text {st }}\right)$, and $f\left(F_{\text {is }}\right)$, were calculated according to Weir and Cockerham [26], and 10,000 replicates were used to produce $95 \%$ bootstrap confidence intervals. We used Wright's [24] method of estimating the number of migrants between populations based on $F_{\text {st }}$, that is, $\mathrm{Nm}=$ $\left(1-F_{\mathrm{st}}\right) /\left(4 F_{\mathrm{st}}\right)$. Linkage disequilibrium was calculated for all locus pairs in each population using Fisher's exact test. GENEPOP was used to conduct a Mantel's [27] test for isolation by distance. Here, a matrix of $F_{\mathrm{st}} /\left(1-F_{\mathrm{st}}\right)$ was compared to geodesic distances and to ln-transformed geodesic distances between cities. A one-tailed probability was obtained following 10,000 permutations.

Estimates of the actual number of populations within the Ailanthus gene pool that we had sampled were obtained using Bayesian clustering software (structure, [28]). Individuals were assigned fractionally to one or more populations in a fashion that maximized the within-population HardyWeinberg and linkage equilibrium. We used the admixture ancestry model with the LOCPRIOR option, allowing sampling locations to serve as prior information to aid clustering where signal was weak. All other settings were default, 


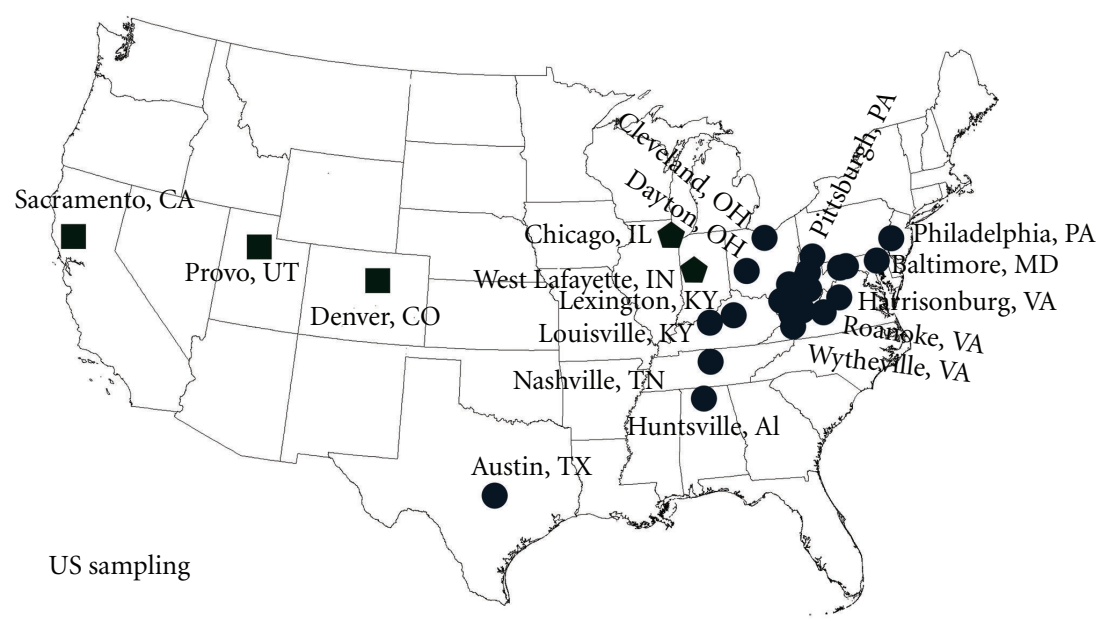

(a)

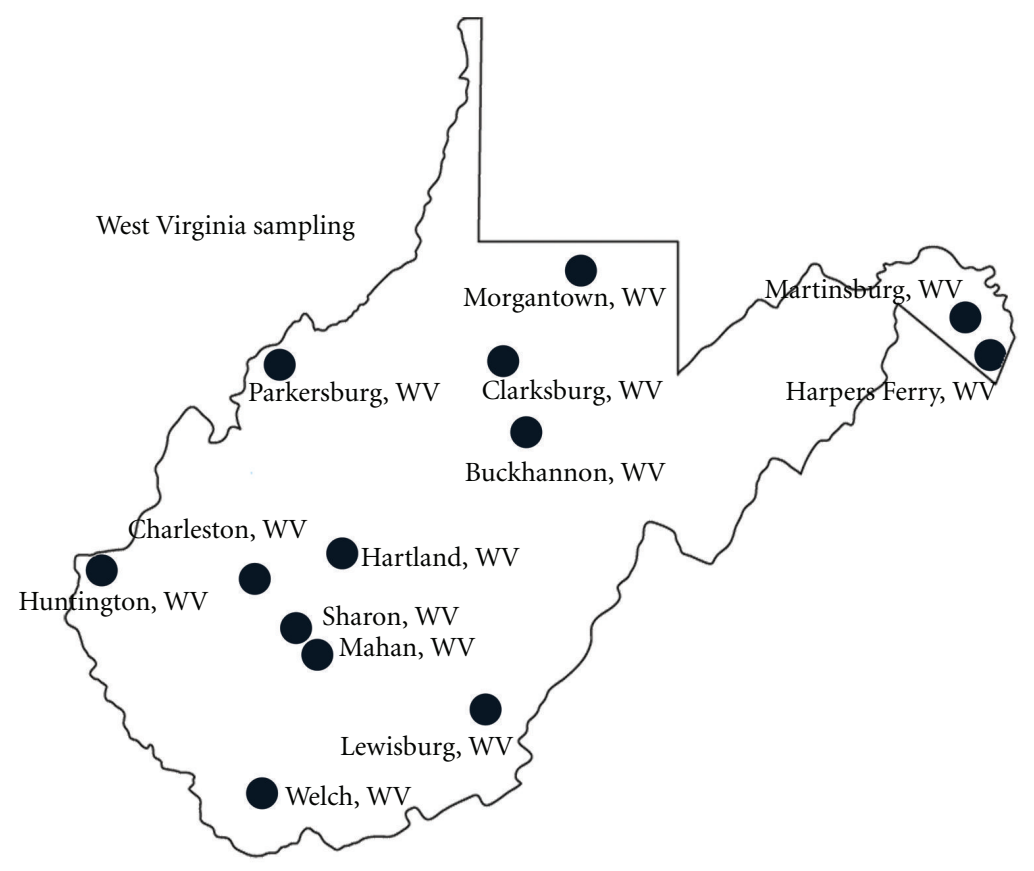

(b)

FIGURE 1: Sampling locations across the US and those concentrated in the state of West Virginia. Square and pentagon symbols were pooled to form CUC and IL/IN samples, respectively.

including the assumption of correlated allele frequencies. Population, or genome, numbers $K=2-28$ were evaluated, each in 10 separate runs involving a burn-in period of 10,000 followed by 50,000 MCMC replicates. The model choice criterion, $\ln P(X \mid K)$, was used to select the most likely out of the 10 runs per each $K$, and among estimates of $K$. The resultant population substructure was visualized using the program distruct [29].

\section{Results}

3.1. Diversity and Endemism. There were no hotspots of allelic diversity in the Ailanthus gene pool revealed by these microsatellite markers (Table 1, Figure 2). The mean number of alleles per locus (6.8, range across loci, 6-9) was moderate, given the large range of the species, and did not vary much across populations. Ten private alleles were found at the population level, and these occurred at a low mean frequency (0.034). Rarefaction analysis (Figure 2) did show that allelic richness was greatest in several Midwestern U.S. cities. Heterozygosities also were moderate and did not vary greatly across populations (Table 1).

There was no statistical difference in the number of alleles in large versus small cities $(P=.194)$, but expected heterozygosities were significantly lower $(P=.049)$ in small 


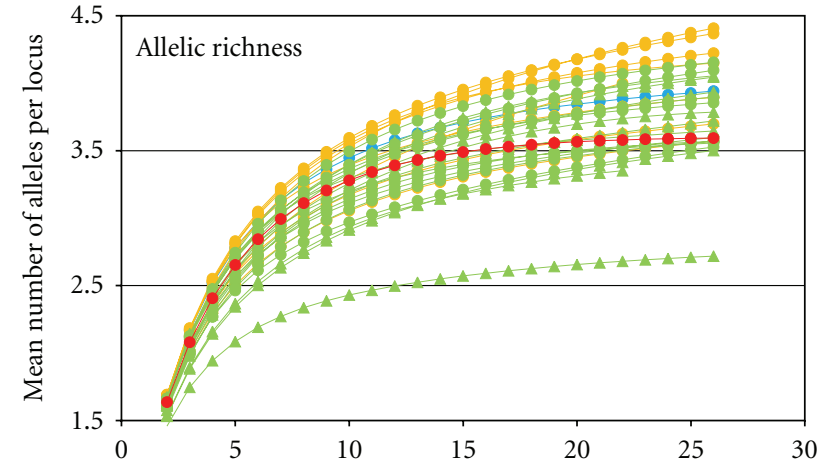

(a)

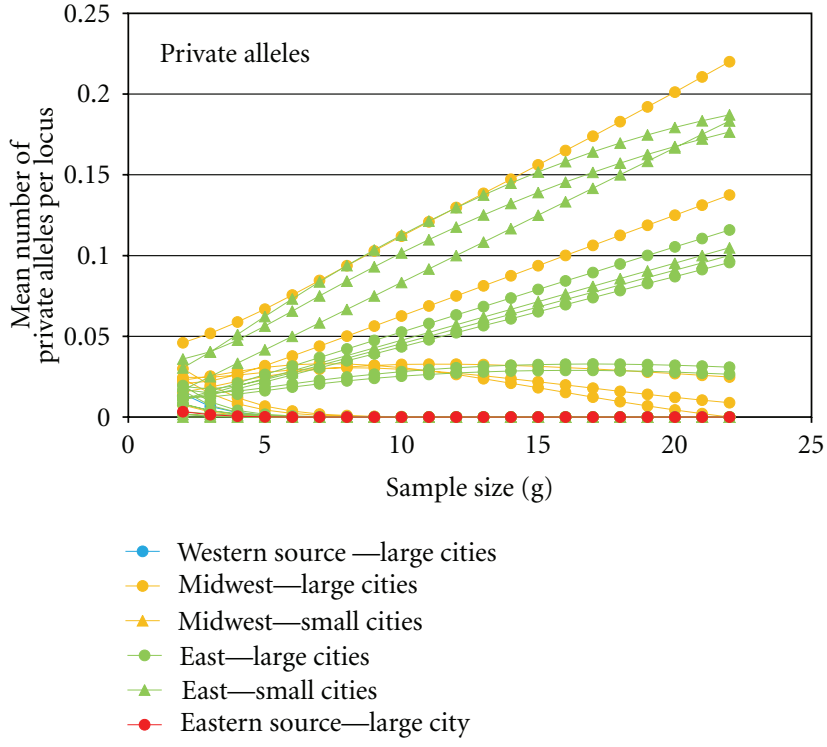

(b)

FIGURE 2: Rarefaction analysis of the Ailanthus gene pool showing sampling trends in allelic richness and private alleles for the 28 populations color coded by region and shape coded by human population size of the city.

cities $\left(H_{e}=0.535\right)$ compared to large cities $\left(H_{e}=0.617\right)$, and the same held for observed heterozygosities (small, $H_{o}=0.584$; large, $\left.H_{o}=0.651 ; P=.006\right)$. Overall mean heterozygosity $\left(H_{o}=0.591\right)$ was only slightly less than expected $\left(H_{e}=0.629\right)$ yielding a deficit of $f=0.062$. Eleven of the 28 cities exhibited a significant deficit and only one a significant excess.

Philadelphia and the far western collections (putative source populations) were not especially variable, carrying no private alleles relative to the other collections. Thirteen alleles (mean frequency $=0.007$ ) were detected in nonsource populations but not found in the putative source populations. Three alleles were shared by the far west and nonsource populations but not present in Philadelphia, and only one allele was shared by Philadelphia and nonsource populations but not the far west.

\subsection{Partitioning of Genetic Variation. Genetic structure as} measured by $F$-statistics was limited but significant (Table 2). Population level and overall inbreeding were both small in magnitude $\left(F_{\text {is }}=0.056\right.$ and $\left.F_{\text {it }}=0.120\right)$, and $95 \%$ confidence intervals included zero for $F_{\text {is }}$, though not $F_{\text {it }}$. Population differentiation was also small $\left(F_{\text {st }}=0.067\right)$, but significantly greater than zero. Based on this information, the number of migrants per generation was $N m=5.36$. The Mantel test revealed no significant isolation by distance genetic structure $(P>.05)$.

Significant linkage disequilibrium was detected, especially in populations from small cities. Of the ten pairwise comparisons among the five loci, roughly a quarter $(23.2 \%)$ were significant in Ailanthus populations from large cities whereas associations were twice that
$(48.9 \%)$ in smaller cities, and this difference was significant $(P=.041)$.

The program structure provided estimates of the number of biological populations present in the sample of 555 Ailanthus stems that we collected. To reiterate, here "biological" is judged by reassigning individual stems to different populations under separate iterations in which a certain number of $K$ populations has been specified, as a hypothesis. Reassignments of stems are judged by their effects on minimizing Hardy-Weinberg and linkage disequilibrium in the data set. In our runs, the variance in parameter $r$ had stabilized by the end of each burn-in period, and we selected the run (out of 10) for each $K$ giving the highest likelihood, ln $P(X \mid K)$. The distribution was multimodal across $K=1-28$ with the smallest optimum at $K=5$ and the global optimum at $K=15$ populations.

The results of the structure analysis, rendered using distruct (Figure 3), revealed a highly reticulate gene pool. For $K=5$ populations, there were two genomes that predominated in Philadelphia, PA, the yellow and the orange, which were well represented elsewhere in the range. However, the red genome which was present at high frequency on the west coast was also broadly distributed all the way to the east coast. The green and blue genomes were present only at low frequencies in the two putative source sites. The green genome occurred all the way from Austin, TX to Richmond, VA with peak abundances in northern West Virginia and Pittsburgh, PA. The blue genome was most common in several small cities in southern West Virginia and Virginia though it occurred at low frequency in adjacent towns. As for $K=15$ populations, the graph of the gene pool was complex, and the pattern was difficult to discern. 
TABLE 2: Summary of gene diversity and $F$-statistics based on five nuclear microsatellite markers.

\begin{tabular}{lcccccccc}
\hline Locus & $n$ & $A$ & $H_{e}$ & $H_{o}$ & $f$ & $F_{\text {is }}$ & $F_{\text {st }}$ \\
\hline Aa22 & 544 & 7 & 0.725 & 0.706 & 0.027 & -0.034 & 0.061 \\
Aa69 & 539 & 6 & 0.662 & 0.646 & 0.025 & -0.026 & 0.052 \\
Aa75 & 538 & 9 & 0.76 & 0.686 & 0.098 & 0.018 & 0.084 \\
Aa76 & 553 & 6 & 0.486 & 0.477 & 0.018 & -0.073 & 0.088 \\
Aa82 & 523 & 6 & 0.745 & 0.459 & 0.385 & 0.351 & 0.027 \\
\hline MEAN & 539.4 & 6.8 & 0.676 & 0.595 & 0.12 & 0.057 & 0.021 \\
\hline
\end{tabular}

$N$, data per locus.

$A$, alleles per locus.

$H_{e}$, expected heterozygosity.

$H_{o}$, observed heterozygosity.

$f$, heterozygote deficit.

$F$-statistics (Wright $[24,25]), F\left(F_{\mathrm{it}}\right), \theta\left(F_{\mathrm{st}}\right)$, and $f\left(F_{\mathrm{is}}\right)$, calculated according to Weir and Cockerham [26].

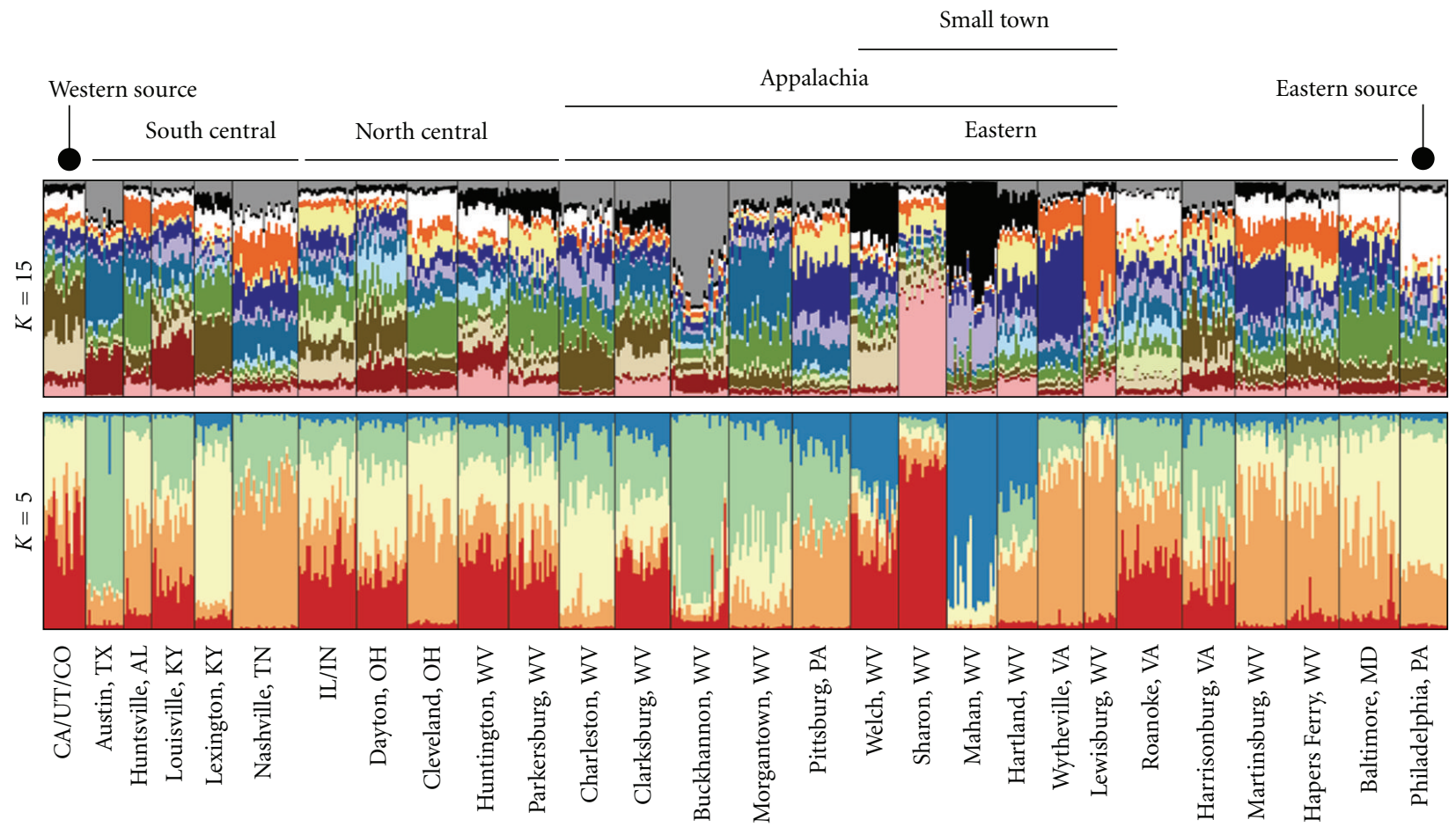

FIGURE 3: Ailanthus population structure as estimated by the program structure [28] rendered using the program distruct [29]. Shown are 28 Ailanthus populations (labeled as sampled) and their inferred gene pool composition based on 5 microsatellite loci. Each population section (bounded by vertical black lines) is comprised of thin vertical colored lines representing the roughly 20 individuals sampled per population. The colors ( $K$ in number) denote each individual's estimated fractional membership in the $K$ populations or genomes hypothesized. Shown are the two separate hypotheses of $K=5$ and $K=15$ populations. For example, under the hypothesis of $K=5$ biological populations, the sample of 20 stems from Mahan, WV contained mostly the blue genome with a little of the yellow genome. Only $23 \mathrm{~km}$ down the road, Sharon, WV contained mostly the red genome with small amounts of the other five genomes. Both Mahan and Sharon had small human population sizes.

\section{Discussion}

The naturalized U.S. gene pool of Ailanthus displayed moderate levels of variation, significant but limited genetic differentiation, and limited correspondence between genetic composition and geographic origin. These findings are consistent with a model of multiple introductions followed by high rates of gene exchange between cities and regions. The genetic evidence supports a role for both east and west coast introductions, but the Philadelphia and west coast samples that we collected did not account for all the variation observed in the study, suggesting additional introductions have contributed to the formation of the naturalized gene pool. We consider some aspects of Ailanthus natural history in light of these data. 
4.1. Diversity and Endemism. While there are enough alleles present in the Ailanthus gene pool that one might expect to see some diversity hotspots, the absence of hotspots is readily explained by the apparent high rate of mixing associated with frequent and long-distance migration events.

It is noteworthy that the highest genetic diversity was found in Midwestern populations. These lie at the confluence between the eastern and western points of introduction and so would be more likely to share otherwise novel variation held by both coastal populations.

For several measures of Ailanthus genetic diversity, there was a significant association between diversity and the size of the human population of a city: typically small cities had less diverse Ailanthus gene pools. The least variable were from fairly isolated, southern Appalachian cities such as Mahan and Lewisburg, WV, and Wytheville, VA. However, given our sampling design, we cannot disentangle geography (west, east) from city size (large, small) since there was a significant association between these attributes $(P=.001)$.

4.2. Partitioning of Genetic Variation. The genetic differentiation among the sampled populations was significant, though small in magnitude. The estimated number of migrants per generation $(\mathrm{Nm}=5.36)$ was fairly high which would tend to erode geographic genetic structure under many circumstances, explaining the failed Mantel test.

The population structure inferred by the program structure suggested a ramified gene pool rather than a clearly partitioned gene pool. This is readily interpreted as resulting from multiple founder events and high rates of gene exchange among established populations.

A portion of the observed heterozygote deficit might owe to the presence of null alleles, possibly at Aa82. However, such a deficit also could arise as a valid signature of one or more evolutionary processes, such as if we had sampled across population substructure arising from clonal reproduction, family structure within a population, or from high rates of migration between populations [30].

4.3. Introduction History. The genetic data support Philadelphia as an early point of introduction for Ailanthus into the U.S., though not the sole conduit. Philadelphia cannot account for all of the alleles detected. Moreover, the population assignments carried out by the program structure showed that while many individuals register a strong genome affinity to the Philadelphia section of the gene pool, many others are more alike the west coast section, and some are like neither. This suggests random genetic drift away from the source sections of the gene pool, mutation-producing novel variants and/or contributions from other sources not sampled in this study. There are other documented introductions into the U.S. including a second arrival from England into Flushing, New York in 1790 [31] and a more recent introduction into Virginia for research purposes by Feret [32].

Our findings comport with prior, though limited, genetic research indicating little or no bottlenecking associated with the arrival of Ailanthus in the U.S. Feret and Bryant [18] studied 15 peroxidase isozymes from U.S. and Chinese Ailanthus and found only moderate differences in frequencies and no unique Chinese alleles. They concluded that the founding event(s) in the U.S. had not purged much of the original variation. Feret et al. [33] studied quantitative genetic variation for height and growth traits relevant to invasiveness and reported significant differences across seed sources in the U.S. but little clear associations between gene pool variation and geography, climate, or soils. They concluded that naturalized Ailanthus had not adapted to microhabitats in the U.S. Similarly, we found small but significant microsatellite differentiation across populations, but little association between geographic distance and microsatellite genetic distance.

4.4. Natural History. Our findings imply that sexual reproduction is common within established Ailanthus populations. Many insects visit the flowers though bees and flies are the largest groups [8], and these vectors could move pollen over fair distances, producing well-mixed city populations. Feret [32] states that the U.S. seed sources he studied showed no signs of inbreeding depression, and our genetic findings show negligible signs of inbreeding.

As for vegetative propagation, Ailanthus can be quite aggressive in its clonal reproduction on a local scale [34], yet genotypic redundancy was very sparse in our study, and there were only limited departures from Hardy-Weinberg expectations in most populations. Had we sampled adjacent stems, we might have detected clonality, and it is possible that apomixis is common at population margins and founding events. These are topics that deserve further attention.

Ailanthus life history suggests the capacity for frequent long-distance dispersal. Wind-dispersed Ailanthus seed can travel $100 \mathrm{~m}$ from an edge into forest interior, and the species can spread rapidly in fragmented landscapes, benefiting from high winds and light [12], but these are local movements and the tails of the dispersal distribution can be critical as well, especially in range expansions $[35,36]$. Kowarik and Säumel [37] demonstrated the capacity for long-distance dispersal of Ailanthus by water, by both seed and stem fragments.

We agree that long-distance moves have fueled the expansion of Ailanthus across the U.S., though we propose that this has occurred mainly by secondary seed dispersal mediated by vehicular traffic. The thin samaras readily slip in between metal fittings on cars, trucks, and trains (Aldrich, pers. obs.) and are apt to travel long distances before being dislodged by wind. Turbulent winds are abundant along highways and rail lines, and Landenberger et al. [12] note that wind facilitates the release of seed from the parent tree. Thus, wind dispersal would be key in moving the seed to and from the secondary dispersal agent. It is already known that Ailanthus often grows in dense thickets along the edges of major highways and railroads [38, 39].

Large cities maintain large standing populations of Ailanthus, and our genetic data imply that they frequently exchange germplasm with other large cities. Chicago, IL stands as one of the most connected cities with regards to vehicular traffic, residing in the heartland of the country but also serving as a major hub for a large amount of truck 
and rail traffic for the rest of the country. In this regard, it is not surprising that Chicago ranked high in all aspects of Ailanthus genetic diversity.

By contrast, our genetic data indicate that Ailanthus populations in small cities are driven more by founder events and genetic drift. The small populations in southern West Virginia and Virginia are separated by relatively few kilometers but otherwise are isolated by mountainous terrain and low rates of traffic along connecting roads. These geographically adjacent towns often display very different genome affinities suggestive of founder events and drift, whereby a small portion of the gene pool is established in a small town and quickly comes to dominate the local habitat. Additional evidence in support of this view comes from linkage disequilibrium which was significantly higher in small cities $(P=.040)$.

\section{Management Considerations}

These genetic findings suggest that the naturalized Ailanthus gene pool is diverse, dynamic, and highly interconnected. Diversity correlates with city size, which in turn is likely to correlate with vehicular traffic, and thus gene pool connectivity. Research currently underway in our group is to examine the Ailanthus gene pool dynamics in this context in order to address modes of regulating dispersal and diversity.

\section{Acknowledgments}

This work was supported by the USDA Forest Service (04-JV11242328-119, 05-JV-11242343-057, and 06-JV-11242343057 to P.R.A. and G.K.G) and the Illinois Board of Higher Education (05S001270001 to P.R.A). The authors thank Benedictine University for support of this research, C.R.H Aldrich for field assistance, and several other volunteers for collections from the western states.

\section{References}

[1] J. W. Clayton, E. S. Fernando, P. S. Soltis, and D. E. Soltis, "Molecular phylogeny of the tree-of-heaven family (simaroubaceae) based on chloroplast and nuclear markers," International Journal of Plant Sciences, vol. 168, no. 9, pp. 1325-1339, 2007.

[2] S. L. Corbett and S. R. Manchester, "Phytogeography and fossil history of Ailanthus (Simaroubaceae)," International Journal of Plant Sciences, vol. 165, no. 4, pp. 671-690, 2004.

[3] S. Hu, "Ailanthus," Arnoldia, vol. 39, pp. 29-50, 1979.

[4] USDA, "N. Ailanthus altissima (Mill.) Swingle, tree of heaven," The PLANTS Database. National Plant Data Center, Baton Rouge, La, USA, 2008, http://plants.usda.gov.

[5] C. D. Huebner, "Vulnerability of oak-dominated forests in West Virginia to invasive exotic plants: temporal and spatial patterns of nine exotic species using Herbarium records and land classification data," Castanea, vol. 68, no. 1, pp. 1-14, 2003.

[6] E. Pan and N. Bassuk, "Establishment and distribution of Ailanthus altissima in the urban environment," Journal of Environmental Horticulture, vol. 4, pp. 1-4, 1986.
[7] H. Gleason and A. Cronquist, Manual of vascular plants of northeastern United States and adjacent Canada, The New York Botanical Garden, Bronx, NY, USA, 2nd edition, 1993.

[8] P. Aldrich, et al., "Floral visitation of the invasive stinking ash in western suburban Chicago," Transactions of the Illinois State Academy of Sciences, vol. 101, pp. 1-12, 2008.

[9] P. Feret, "Early flowering in Ailanthus," Forest Science, vol. 19, pp. 237-239, 1973.

[10] G. Bory and D. Clair-Maczulajtys, "Production, dissemination and polymorphism of seeds in Ailanthus altissima," Revue Generale de Botanique, vol. 88, pp. 297-311, 1980.

[11] G. R. Matlack, "Diaspore size, shape, and fall behaviour in wind-dispersed plant species," American Journal of Botany, vol. 74, no. 8, pp. 1150-1160, 1987.

[12] R. E. Landenberger, N. L. Kota, and J. B. McGraw, "Seed dispersal of the non-native invasive tree Ailanthus altissima into contrasting environments," Plant Ecology, vol. 192, no. 1, pp. 55-70, 2007.

[13] F. Mergen, "A toxic principle in the leaves of Ailanthus," Botanical Gazette, vol. 121, pp. 32-36, 1959.

[14] R. M. Heisey, "Allelopathic and herbicidal effects of extracts from tree of heaven (Ailanthus altissima)," American Journal of Botany, vol. 77, no. 5, pp. 662-670, 1990.

[15] R. M. Heisey, "Evidence for allelopathy by tree-of-heaven (Ailanthus altissima)," Journal of Chemical Ecology, vol. 16, no. 6, pp. 2039-2055, 1990.

[16] V. De Feo, L. De Martino, E. Quaranta, and C. Pizza, "Isolation of phytotoxic compounds from tree-of-heaven (Ailanthus altissima swingle)," Journal of Agricultural and Food Chemistry, vol. 51, no. 5, pp. 1177-1180, 2003.

[17] I. Kowarik and I. Säumel, "Biological flora of Central Europe: Ailanthus altissima (Mill.) Swingle," Perspectives in Plant Ecology, Evolution and Systematics, vol. 8, no. 4, pp. 207-237, 2007.

[18] P. Feret and R. Bryant, "Genetic differences between American and Chinese Ailanthus seedlings," Silvae Genetica, vol. 23, pp. 144-148, 1974.

[19] P. R. Aldrich, C. H. Michler, W. Sun, and J. Romero-Severson, "Microsatellite markers for northern red oak (Fagaceae: Quercus rubra)," Molecular Ecology Notes, vol. 2, no. 4, pp. 472-474, 2002.

[20] J. F. Dallas, M. J. B. Leitch, and P. E. Hulme, "Microsatellites for tree of heaven (Ailanthus altissima)," Molecular Ecology Notes, vol. 5, no. 2, pp. 340-342, 2005.

[21] P. Lewis and D. Zaykin, "Genetic Data Analysis: Computer program for the analysis of allelic data. Genetic Data Analysis: Computer program for the analysis of allelic data," 2001, http://lewis.eeb.uconn.edu/lewishome/software.html.

[22] M. Raymond and F. Rousset, "GENEPOP (version 1.2): population genetics software for exact tests and ecumenicism," Journal of Heredity, vol. 86, pp. 248-249, 1995.

[23] Z. A. Szpiech, M. Jakobsson, and N. A. Rosenberg, "ADZE: a rarefaction approach for counting alleles private to combinations of populations," Bioinformatics, vol. 24, no. 21, pp. 24982504, 2008.

[24] S. Wright, "The genetical structure of populations," Annals of Eugenics, vol. 15, pp. 323-354, 1951.

[25] S. Wright, "The interpretation of population structure by Fstatistics with special regard to systems of mating," Evolution, vol. 19, pp. 395-420, 1965.

[26] B. S. Weir and C. C. Cockerham, "Estimating F-statistics for the analysis of population structure," Evolution, vol. 38, no. 6, pp. 1358-1370, 1984. 
[27] N. Mantel, "The detection of disease clustering and a generalized regression approach," Cancer Research, vol. 27, no. 2, pp. 209-220, 1967.

[28] J. K. Pritchard, M. Stephens, and P. Donnelly, "Inference of population structure using multilocus genotype data," Genetics, vol. 155, no. 2, pp. 945-959, 2000.

[29] N. A. Rosenberg, "DISTRUCT: a program for the graphical display of population structure," Molecular Ecology Notes, vol. 4, no. 1, pp. 137-138, 2004.

[30] P. Hedrick, Genetics of Populations, Jones and Bartlett, Sudbury, Mass, USA, 2nd edition, 2000.

[31] P. Davies, "The history, distribution, and value of Ailanthus," Transactions of the Kentucky Academy of Sciences, vol. 9, pp. 12-14, 1942.

[32] P. Feret, "Ailanthus: variation, cultivation, and frustration," Journal of Arboriculture, vol. 11, pp. 361-368, 1985.

[33] P. P. Feret, R. L. Bryant, and J. A. Ramsey, "Genetic variation among American seed sources of Ailanthus altissima (Mill.) Swingle," Scientia Horticulturae, vol. 2, no. 4, pp. 405-411, 1974.

[34] I. Kowarik, "Clonal growth in Ailanthus altissima on a natural site in West Virginia," Journal of Vegetation Science, vol. 6, no. 6, pp. 853-856, 1995.

[35] S. Portnoy and M. F. Willson, "Seed dispersal curves: Behavior of the tail of the distribution," Evolutionary Ecology, vol. 7, no. 1, pp. 25-44, 1993.

[36] S. I. Higgins and D. M. Richardson, "Predicting plant migration rates in a changing world: the role of long-distance dispersal," American Naturalist, vol. 153, no. 5, pp. 464-475, 1999.

[37] I. Kowarik and I. Säumel, "Water dispersal as an additional pathway to invasions by the primarily wind-dispersed tree Ailanthus altissima," Plant Ecology, vol. 198, no. 2, pp. 241252, 2008.

[38] R. Stipes, "A tree grows in Virginia," Virginia Journal of Science, vol. 46, p. 105, 1995.

[39] R. W. Merriam, "The abundance, distribution and edge associations of six non-indigenous, harmful plants across North Carolina," Journal of the Torrey Botanical Society, vol. 130, no. 4, pp. 283-291, 2003. 

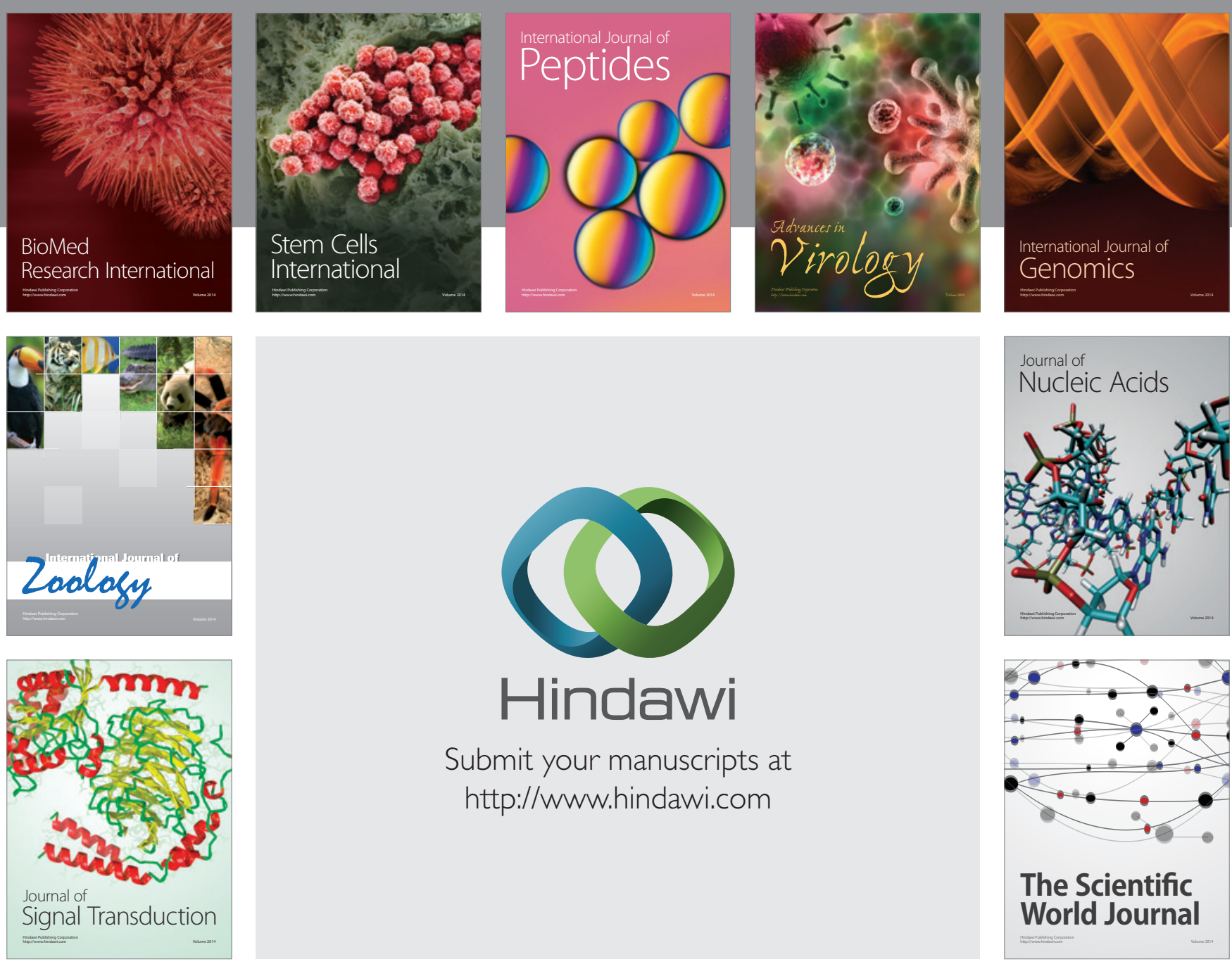

Submit your manuscripts at

http://www.hindawi.com
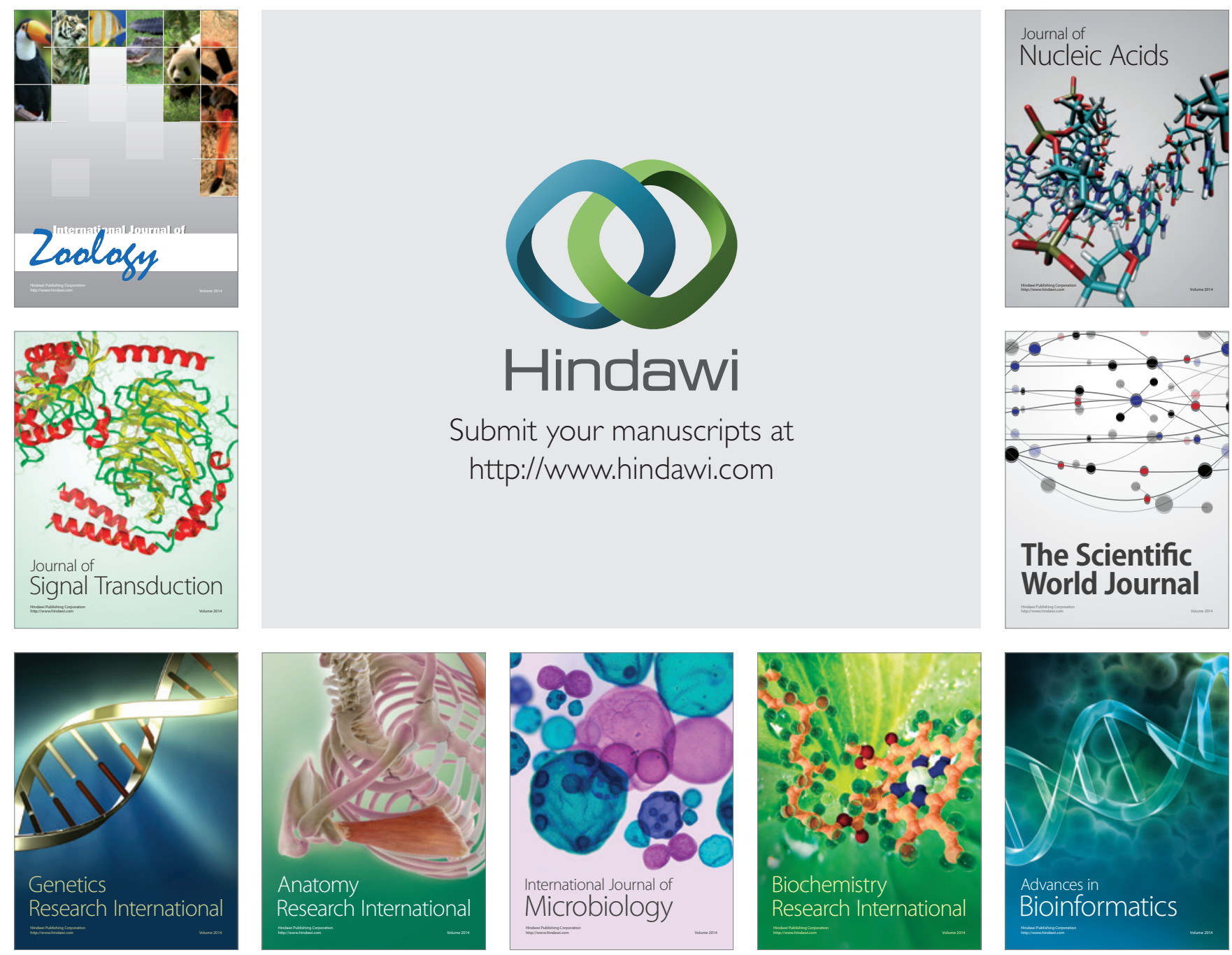

The Scientific World Journal
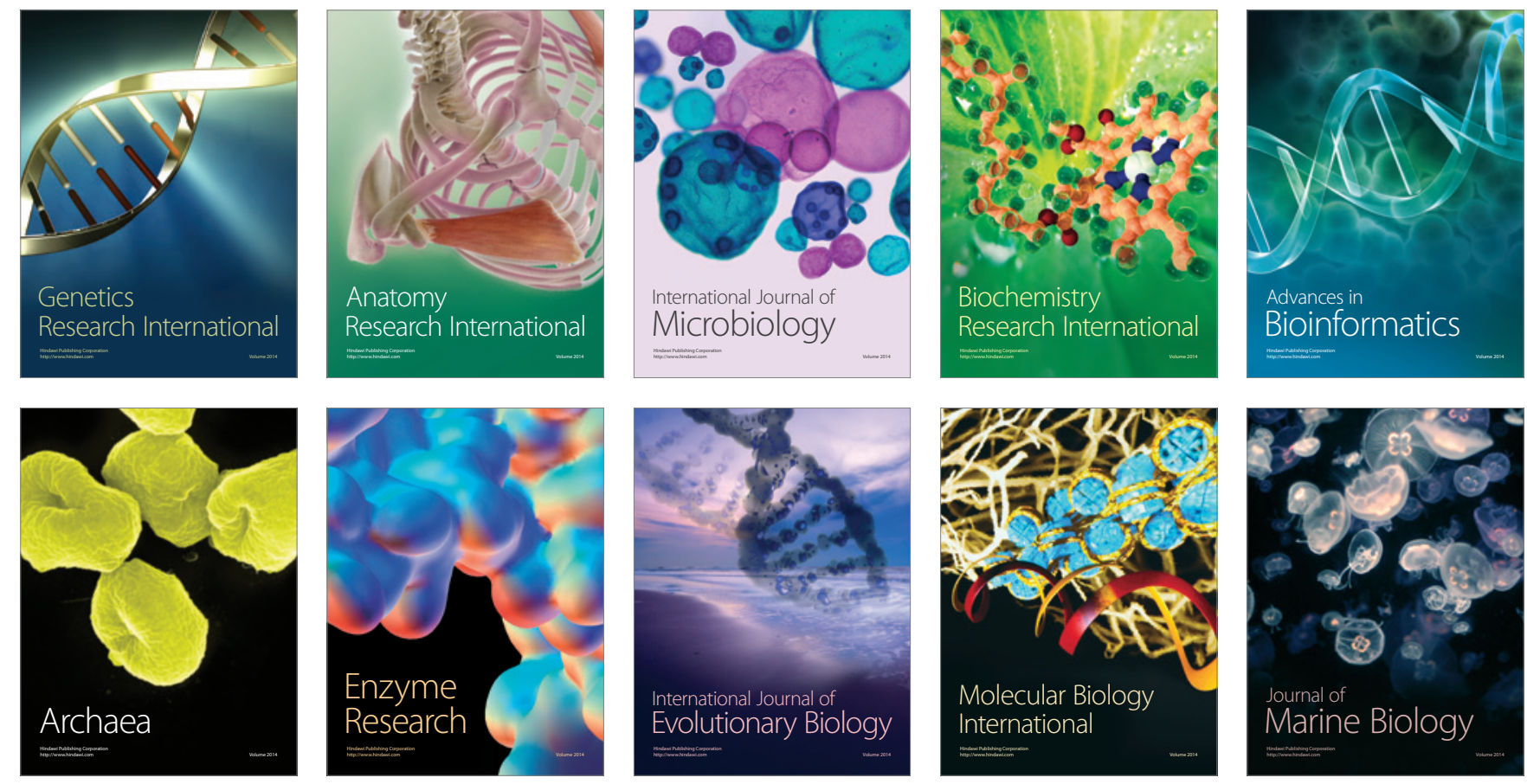